\title{
Universal health coverage, health systems strengthening, and the World Bank
}

\author{
In the second article of the series, Marlee Tichenor and Devi Sridhar discuss how the World \\ Bank is promoting better access to healthcare
}

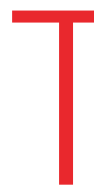
he sustainable development goals (SDGs) formally promote universal health coverage as a key objective for the global health community. This focus on universal health coverage arose both from a desire to maintain the health gains achieved by the millennium development goals and from criticism that those goals were short term in nature and narrowly focused on disease specific approaches. ${ }^{12}$

On 12 December 2012, universal health coverage had unequivocal endorsement from the UN General Assembly (including the United States) with the approval of a resolution that confirmed the "intrinsic role of health in achieving international sustainable development goals." ${ }^{3}$ Also in 2012, a World Health Organization discussion paper on the post-2015 health agenda (what would emerge as the SDGs) identified universal health coverage as a "way of bringing all programmatic interests under an inclusive umbrella." ${ }^{4}$ The 2014

\section{REY MESSAGES}

- In the era of sustainable development goals, the World Bank plays a pivotal role in promoting universal health coverage and strengthening health systems. In 2010, the bank provided $32 \%$ of the global health systems support budget

- The World Bank's health policy focus has shifted from population control (1970s), to primary healthcare direct lending (1980-6), to health reform (1987-96), to the enhancement of healthcare systems (19972007), to a health systems approach (2007-present)

- The World Bank has a comparative advantage over WHO to lead the universal health coverage agenda given its access to ministries of finance, its staff expertise in measurement, its broad multisectorial portfolio, and its lending power

- The World Bank's expanded role in global health carries with it the risks of further privatisation of the health sector and major tension between its mandate and the right to health at the heart of universal health coverage
Ebola virus outbreak struck in the middle of deliberations on the SDGs, and reviews of the global health community's response to the epidemic have emphasised the importance of health systems strengthening to achieving equitable, accessible, and resilient healthcare. ${ }^{56}$

In this paper, we examine the World Bank's past and present role in health systems strengthening within the current global health architecture, and critically analyse several points this raises.

\section{The governance of health systems strengthening}

Despite universal health coverage's growing prominence, the term and its relationship to health systems strengthening are under debate. ${ }^{7}$ To better understand trends in the World Bank's investment in health systems and its role in promoting universal health coverage, we must find workable definitions for the terms. The World Bank defines health systems as "the combination of resources, organisation, financing, and management that culminate in the delivery of health services to the population." While WHO's definition is "all activities whose primary purpose is to promote, restore, and maintain health." 89 The term "health systems" has, in the last decade and a half, brought with it systems thinking. As a result, health systems-which are understood to include public and private sectors, communities and families, and health financing bodies and pharmaceutical companies, among other health related organisations-are understood to be "complex adaptive systems" that are continually reorganising in "both formal and informal ways" and unpredictably reacting to inputs into the system. ${ }^{910}$

Within the SDGs, universal health coverage includes "financial risk protection, access to quality essential healthcare services, and access to safe, effective, quality, and affordable essential medicines and vaccines for all." ${ }^{11}$ Health systems strengthening, then, is often taken to indicate the actions taken to achieve the goal of universal health coverage and is often framed as the horizontal approach in contrast to disease specific or vertical approaches. ${ }^{1213}$

Because the definition of a health system is different in different organisations, the means of strengthening it are similarly varied. The bank emphasises that strengthening health systems requires attending to the many actors, commodity chains, policies, and financing mechanisms that make up a country's health system. To the bank, strengthening health systems involves "enhancing public-private partnerships," "setting up the right payment mechanisms," and "ensuring the right logistics," among many other interventions. ${ }^{9}$

However, the bank's approach is just one of several institutions in the global architecture (table 1, figures 1, 2, 3). For example, in recent years the Global Fund to Fight HIV/AIDS, Tuberculosis, and Malaria, along with Gavi, have increasingly channelled funding to strengthening health systems, albeit with a restricted agenda tied to these three diseases, thereby promoting a diagonal approach that mirrors the 1980 s movement of "selective primary healthcare" (table 1). WHO first focused on the right to health at its 1978 Alma-Ata Conference; in recent years, however, it has focused on technical support through creating better metrics for measuring progress towards universal health coverage and quality of strengthening health systems. ${ }^{14}$ The Bill and Melinda Gates Foundation is largely involved with the universal health coverage agenda through its work with WHO and the World Bank on their existing initiatives and supporting the Global Financing Facility at the World Bank. ${ }^{15}$

\section{The World Bank's history in strengthening health systems}

Since its first funded health project in Jamaica in 1970, the World Bank has devoted much of its health financing to strengthening health systems, defining that elusive term here as a broad based, multisectorial, and infrastructural approach to developing health systems. Using the Independent Evaluation Group's timeline, the bank's policy focus has shifted from population control in the 1970 s, to primary healthcare direct lending from 1980 to 1986, to health reform from 1987 to 1996 , to the enhancement of healthcare systems from 1997 to 2007, to a health systems approach from 2007 to the present. ${ }^{213}$

The inaugural health sector project in Jamaica marked the first trend in the 


\begin{tabular}{|c|c|c|c|c|c|}
\hline $\begin{array}{l}\text { Name of } \\
\text { organisation }\end{array}$ & HSS investment in 2013 & $\begin{array}{l}\text { Key historic milestones/ } \\
\text { partnerships }\end{array}$ & Current strategy & In-country contact & Relative strengths \\
\hline \multirow[t]{5}{*}{ WHO } & \multirow[t]{5}{*}{$\$ 608 m$} & $\begin{array}{l}\text { 1975: Primary healthcare strategy } \\
\text { launched }\end{array}$ & \multirow{2}{*}{$\begin{array}{l}\text { UHC monitoring framework with the World Bank, } \\
\text { based on two core components of UHC: coverage } \\
\text { of the population with quality, essential health } \\
\text { services; and coverage of the population with } \\
\text { financial protection }\end{array}$} & \multirow[t]{2}{*}{ In-country offices } & \multirow[t]{2}{*}{ Technical support } \\
\hline & & $\begin{array}{l}\text { 1978: co-sponsors Alma-Ata } \\
\text { International Conference with Unicef }\end{array}$ & & & \\
\hline & & $\begin{array}{l}\text { 1987: co-sponsors the Bamako } \\
\text { initiative with Unicef }\end{array}$ & \multirow[t]{2}{*}{$\begin{array}{l}\text { Primary healthcare performance initiative with } \\
\text { World Bank and Gates Foundation }\end{array}$} & \multirow[t]{2}{*}{ Ministries of health } & \multirow{2}{*}{$\begin{array}{l}\text { UHC main priority of } \\
\text { incoming director } \\
\text { general }\end{array}$} \\
\hline & & $\begin{array}{l}\text { 2000: WHO health report on health } \\
\text { systems }\end{array}$ & & & \\
\hline & & $\begin{array}{l}\text { 2005: World Health Assembly } \\
\text { Resolution } 58.33 \text { on universal health } \\
\text { coverage }\end{array}$ & $\begin{array}{l}\text { UHC2030; UHC partnership; social health } \\
\text { protection network }\end{array}$ & & \\
\hline \multirow[t]{4}{*}{ World Bank } & \multirow{4}{*}{$\begin{array}{l}\$ 1086 \mathrm{~m} \\
\text { (This figure excludes the } \\
\text { bank's trust funds in HSS, } \\
\text { which we estimate to be } \\
\text { another } \$ 189 \mathrm{~m} \text { ) }\end{array}$} & $\begin{array}{l}\text { 1980-6: primary healthcare direct } \\
\text { lending }\end{array}$ & $\begin{array}{l}\text { UHC monitoring framework with WHO (more } \\
\text { above) }\end{array}$ & In-country offices & Technical support \\
\hline & & $\begin{array}{l}\text { 1986: Financing Health Services } \\
\text { in Developing Countries document } \\
\text { introduces user charges }\end{array}$ & $\begin{array}{l}\text { Primary healthcare performance initiative with } \\
\text { WHO and Gates Foundation }\end{array}$ & Ministries of finance & $\begin{array}{l}\text { Access to ministers } \\
\text { of finance }\end{array}$ \\
\hline & & $\begin{array}{l}\text { 1993: World Development Report } \\
\text { emphasises essential services }\end{array}$ & Committing $\$ 15$ billion 2016-20 to UHC in Africa & & $\begin{array}{l}\text { Capacity for } \\
\text { and experience } \\
\text { in sector-wide } \\
\text { approaches }\end{array}$ \\
\hline & & $\begin{array}{l}\text { 2007: Healthy development } \\
\text { emphasises importance of } \\
\text { strengthening health systems; } \\
\text { Health results innovation trust fund } \\
\text { established }\end{array}$ & $\begin{array}{l}\text { Global financing facility } \\
\text { UHC2030 }\end{array}$ & & $\begin{array}{l}\text { Ability to leverage } \\
\text { alternate means of } \\
\text { finance }\end{array}$ \\
\hline \multirow[t]{4}{*}{ Unicef } & \multirow[t]{4}{*}{$\$ 42 m$} & $\begin{array}{l}\text { Mid-1960s: requests that WHO invest } \\
\text { in strengthening health systems }\end{array}$ & \multirow{3}{*}{$\begin{array}{l}\text { HSS are "actions that establish sustained } \\
\text { improvements in the provision, utilisation, quality, } \\
\text { and efficiency of health services, broadly defined } \\
\text { to include family care, preventive services, } \\
\text { - and curative care, and that produce equitable } \\
\text { health, nutrition, and development outcomes for } \\
\text { children, adolescents, and women" }\end{array}$} & \multirow[t]{3}{*}{ In-country offices } & \multirow[t]{3}{*}{ Local engagement } \\
\hline & & $\begin{array}{l}\text { 1978: co-sponsors Alma-Ata } \\
\text { Conference with WHO }\end{array}$ & & & \\
\hline & & $\begin{array}{l}\text { 1982: Unicef's version of “selective } \\
\text { primary healthcare," growth } \\
\text { monitoring, oral rehydration, } \\
\text { breastfeeding, and immunisations } \\
\text { (GOBI) launched }\end{array}$ & & & \\
\hline & & $\begin{array}{l}\text { 1987: co-sponsors Bamako initiative } \\
\text { with WHO }\end{array}$ & $\begin{array}{l}\text { Its "seven step approach to situation analysis and } \\
\text { identification of priority actions in HSS" include } \\
\text { identifying underserved groups and solutions to } \\
\text { bottlenecks in coverage determinants } \\
\text { UHC2030 }\end{array}$ & $\begin{array}{l}\text { Various government } \\
\text { departments such } \\
\text { as National Agency } \\
\text { for Statistics and } \\
\text { Demography }\end{array}$ & $\begin{array}{l}\text { Training of health } \\
\text { workers }\end{array}$ \\
\hline \multirow[t]{2}{*}{$\begin{array}{l}\text { Gavi, the } \\
\text { vaccine } \\
\text { alliance }\end{array}$} & \multirow[t]{2}{*}{$\$ 144 m$} & $\begin{array}{l}\text { 2005: Gavi board first takes steps to } \\
\text { widen support of HSS, recognising } \\
\text { that immunisation coverage is } \\
\text { dependent on "strong service } \\
\text { systems" }\end{array}$ & $\begin{array}{l}\text { The second of Gavi's four goals in its PHASE IV } \\
2016-20 \text { work is "the systems goal” to "increase } \\
\text { effectiveness and efficiency of immunisation } \\
\text { delivery as an integrated part of strengthened } \\
\text { health systems" }\end{array}$ & $\begin{array}{l}\text { No in-country } \\
\text { presence }\end{array}$ & \multirow[t]{2}{*}{$\begin{array}{l}\text { Uses vaccine } \\
\text { distribution chains } \\
\text { to strengthen } \\
\text { health systems }\end{array}$} \\
\hline & & $\begin{array}{l}\text { 2009: commissioned review of Gavi’s } \\
\text { health system strengthening support }\end{array}$ & UHC2030 & $\begin{array}{l}\text { Partners with } \\
\text { UNICEF and WHO } \\
\text { for in-country } \\
\text { distribution }\end{array}$ & \\
\hline \multirow[t]{2}{*}{$\begin{array}{l}\text { Global Fund } \\
\text { to Fight AIDS, } \\
\text { Tuberculosis, } \\
\text { and Malaria }\end{array}$} & \multirow[t]{2}{*}{$\$ 1246 m$} & \multirow[t]{2}{*}{$\begin{array}{l}\text { 2007: Round } 7 \text { grants granted } \\
\text { HSS support with disease specific } \\
\text { component }\end{array}$} & $\begin{array}{l}\text { The Global Fund's \$9bn commitment for } 2017 \\
\text { through } 2019 \text { includes } \$ 3 \text { bn of investments } \\
\text { in systems for health such as strengthened } \\
\text { procurement systems and supply chains, } \\
\text { improved data quality and data management } \\
\text { systems, and strengthened human resources } \\
\text { for health }\end{array}$ & $\begin{array}{l}\text { No in-country } \\
\text { presence }\end{array}$ & \multirow{2}{*}{$\begin{array}{l}\text { Uses investments } \\
\text { in HIV/AIDS, TB, } \\
\text { and malaria to } \\
\text { strengthen health } \\
\text { systems, mirroring } \\
\text { the selective } \\
\text { primary healthcare } \\
\text { movement of the } \\
\text { 1980s }\end{array}$} \\
\hline & & & UHC2030 & $\begin{array}{l}\text { Country coordinating } \\
\text { mechanism }\end{array}$ & \\
\hline \multirow{2}{*}{$\begin{array}{l}\text { Bill and } \\
\text { Melinda } \\
\text { Gates } \\
\text { Foundation }\end{array}$} & \multirow{2}{*}{$\begin{array}{l}\$ 100 \mathrm{~m} \\
\text { (\$146m through the other } \\
\text { organisations listed above) }\end{array}$} & \multirow{2}{*}{$\begin{array}{l}\text { 2013: publish a document that states } \\
\text { that UHC "has much to commend it } \\
\text { in terms of an aspirational goal" but } \\
\text { "due to the lack of robust evidence } \\
\text { of links between UHC... and the } \\
\text { desired impact of improved health } \\
\text { outcomes," the Gates Foundation } \\
\text { does not agree it should be included } \\
\text { in the SDGs }\end{array}$} & $\begin{array}{l}\text { Primary healthcare performance initiative with } \\
\text { World Bank and WHO }\end{array}$ & $\begin{array}{l}\text { No in-country } \\
\text { presence }\end{array}$ & Extreme flexibility \\
\hline & & & $\begin{array}{l}\text { Major involvement with global financing facility; } \\
\text { UHC2030 }\end{array}$ & $\begin{array}{l}\text { Variable, depends on } \\
\text { country and project }\end{array}$ & \\
\hline
\end{tabular}

$\mathrm{UHC}=$ universal health coverage; $\mathrm{HSS}=$ health system strengthening. 


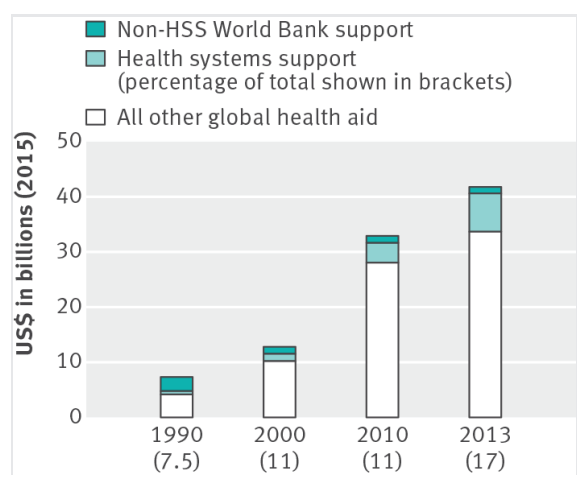

Fig 1 | Health systems support in development assistance for health ${ }^{16171819}(2013$ is included because it is the most recent year with complete breakdowns for financial contributions on the Institute for Health Metrics and Evaluation website)

bank's policy focus in health: population control. Of the $\$ 2 \mathrm{~m}(€ 1.6 \mathrm{~m} ; € 1.8 \mathrm{~m})$ invested in the programme, $84 \%$ was spent on the expansion and remodelling of Jamaica's major maternity hospital and the construction of 10 rural maternity centres. With important exceptions-like the Onchocerciasis Control Programme established in $1974^{18}$-the bank's early interest in the health sector was rooted in its desire to "slow down population growth," ease "population pressure," and thereby mitigate its "heavy strain on government expenditures on education, health, and housing" in the global south. ${ }^{20}$ It was within this context of population control that the bank supported infrastructural and technical support of health services.

In 1981, the bank initiated the health and population project in Tunisia, which was arguably its first project explicitly promoting basic healthcare. The project corresponded with a policy shift away from population control towards tackling growing urban-rural disparities and emphasising a preventative approach to healthcare over a curative one. This shift

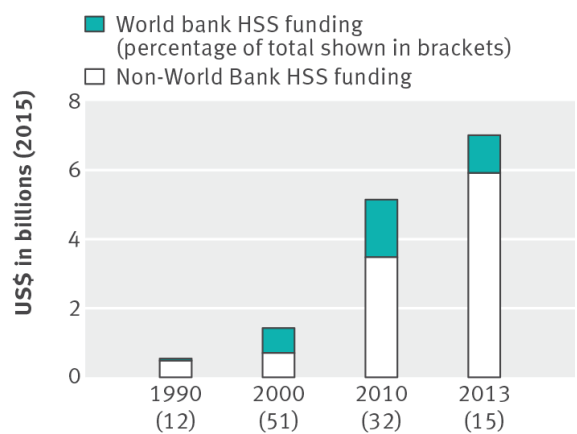

Fig 2 | Financial contribution of the World Bank to health systems strengthening ${ }^{16171819}$ ( 2013 is included because it is the most recent year with complete breakdowns for financial contributions on the Institute for Health Metrics and Evaluation website)

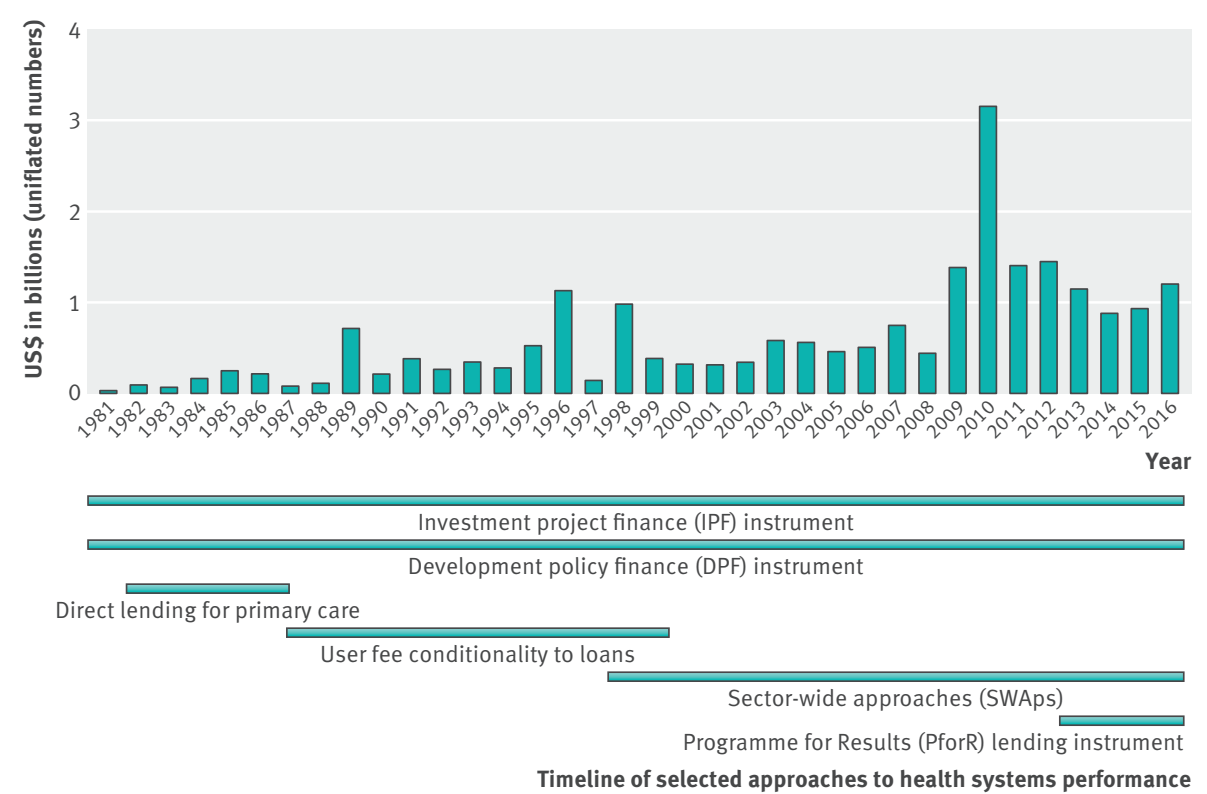

Fig 3 | World Bank commitments to health systems performance

towards primary healthcare was a part of international health development's emphasis on "health for all" following the Alma-Ata Declaration of 1978. However, because of what the bank saw as systematic constraints that served as obstacles to providing more efficient and equitable health services, it restructured its approach to health sector funding, which is outlined in their 1986 policy document. ${ }^{13}$

It is in this document-which calls for health reform and more attention to the world's poor-that the bank's population, health, and nutrition department (HNP) introduced user charges as a means to equalise access to government run health services in developing countries. They argued that user charges could help make health systems more equitable, considering that the rich-who benefit most from public services-would have to pay. This would theoretically free up government resources that could be directed at programmes and facilities for the poor. ${ }^{21}$ Like WHO and Unicef's Bamako Initiative after it, the introduction of user charges led to a further widening of health inequities in many contexts in the global south, producing results at odds with the policies' intentions. $^{2223}$

As a result of its health investment restructuring, the bank came to fund "umbrella" projects with other international health financiers at the end of the 1980 s and in the early 1990s. These incorporated "capacity building" within larger projects on maternal health and nutrition. The Independent Evaluation Group has pointed out that this restructuring actually isolated bank funded projects from the health ministries of recipient countries and contributed to the fragmentation that had become increasingly part of global health aid. ${ }^{24}$ The sector-wide approach was introduced in 1997 as a means to "overcome inefficiencies, lack of government ownership, and a number of other problems" constraining international aid. ${ }^{25}$

The HNP's 2007 Healthy Development policy document explicitly took on the work and language of health systems strengthening, and re-emphasised the connection between the bank's goal of eradicating poverty with the financial constraints and risks that illness put on the world's poor. ${ }^{9}$ Since 2007 , the bank's investment in strengthening health systems has included many new approaches to financing-for example, the Health Results Innovation Trust Fund, established in 2007; the lending instrument Programme for Results Financing established in 2011; and the recently launched Global Financing Facility. These are all mechanisms with which the bank aims to capture more resources for countries' health systems for the promotion of equitable, financially accessible healthcare. With these mechanisms, the bank emphasises the importance of including private health services within a holistic view of strengthening health systems. The Programme for Results Financing was established as the third arm next to the bank's longstanding investment project finance and development policy finance instruments (figure 3 ). Within the context of innovative financing, there have been some questions about the limits of results based financing, as the Health Results Innovation Trust Fund and Programme for Results Financing lent on the condition of countries' ability to prove they met certain health indicators. The Global Financing 
Facility has explicitly not incorporated requirements for results based financing in its framework because of backlash. ${ }^{15}$

The bank's current portfolio in strengthening health systems includes project loans, trust funds, partnerships, new lending instruments, and general budget support, among other modalities. Included within this portfolio are partnerships such as the Primary Health Care Performance Initiative and the International Health Partnership, which provide platforms for coordinating between multiple modes of defining, supporting, and measuring strengthening health systems. Along with the World Bank contributions discussed above, figure 3 provides a timeline of trends of when some approaches to strengthening health systems and lending instruments have been introduced and phased out.

\section{Benefits and risks of the bank's expanding role} With its long standing interest and involvement in broad based health systems support and experience with innovative financing, the bank has strengths that can support universal health coverage. Firstly, because it has access to ministries of finance, the bank can push for universal health coverage in the way no other global health agency can. Secondly, because it is simultaneously a knowledge bank with expert staff, it can drive the development of metrics for monitoring progress towards universal health coverage. In 2015, as a means to monitor countries' progress towards the goal, WHO and the bank published the first report on measuring universal health coverage, using both the indicator of service coverage and the indicator of financial protection, and putting into motion the close monitoring many believe is necessary for progress towards universal health coverage. ${ }^{26}$ Thirdly, with its broad portfolio including education, water and sanitation, and transport, the bank can work across sectors to address broader determinants of healthcare access. Finally, with these financial, logistical, and scientific resources on hand, it can leverage the money needed to promote transformative health policy.

However, at least two major risks accompany these potential benefits. Firstly, the bank has been criticised for promoting a diminished role for the state and encouraging the private sector in public health efforts in the global south, through strategies such as structural adjustment programmes and the introduction of user fees, which has increased inequality in some of the poorest countries in the world..$^{22}$ The move towards funding private hospitals, clinics, and health insurance (such as the Health in Africa initiative) has also been criticised for not reaching those most in need. ${ }^{27}$

Secondly, the bank's mandate to create new markets is often in tension with the fundamental concept at the heart of universal health coverage - that access to non-ruinous, quality healthcare is a human right. The idea of universal health coverage is firmly rooted in the right to health, set out in the International Covenant on Economic, Social, and Cultural Rights. ${ }^{28}$ The bank's Articles of Agreement, however, state explicitly that it shall not be involved politically with member states and only be motivated by technical and economic considerations. Because of the bank's role in the promotion of universal health coverage, how it manages this tension will be critical to achieving global access to equitable healthcare.

\section{Universal health coverage: technical or political goal?}

At the start of the 21st century, the push for universal health coverage seems stronger than ever. The new WHO director general, Tedros Adhanom Ghebreyesus, asserts that the global health community is recommitted to health as a human right with universal health coverage, echoing the commitments made in 1948 and $1978 .{ }^{29}$ Over the past decade, WHO and the World Bank have pointed to a lack of metrics for strengthening health systems as hampering efforts. In fact, in a 2013 speech, bank president Jim Kim argued that the Alma-Ata Declaration's Health for All goal can be achieved in the contemporary era because we have the capacity to measure success towards that goal. ${ }^{30}$ Yet, while global efforts and consensus towards the importance of universal health coverage are crucial, the real driver of change will come from national stakeholders such as health workers demanding the right to health and pressuring governments to find the mechanisms to deliver this goal. Such political movements have already happened all over the world-such as the launch of Senegal's Agence de la couverture maladie universelle in 2013, on the heels of years of health union engagement; Thailand's Universal Coverage Scheme, established in 2001; and Brazil's Unified Health System, established in $1988 .^{31-33}$

Contributors and sources: MT collected the data, analysed it, and drafted the initial version of the paper. DS helped conceptualise and design the study and revised the draft. Competing interests: We have read and understood BMJ policy on declaration of interests and have no relevant interests to declare. This work was supported by the Wellcome Trust [106635/Z/14/Z]. A senior member of the World Bank is on our project's advisory board.

Provenance and peer review: Commissioned; externally peer reviewed.
This article is one of a series commissioned by The $B M /$ based on an idea by the University of Edinburgh. The BM/ retained full editorial control over commissioning, external peer review, editing, and publication. Open access fees are funded by the Wellcome Trust.

Marlee Tichenor, postdoctoral research fellow

Devi Sridhar, professor and chair in global public health

University of Edinburgh, Edinburgh, UK

Correspondence to: M Tichenor

Marlee.Tichenor@ed.ac.uk

United Nations Economic and Social Council. Progress toward the sustainable development goals. 2016. www.un.org/ga/search/view_doc. asp?symbol=E/2016/75\&Lang=E.

2 Independent Evaluation Group. Approach paper: IEG evaluation of World Bank Group support to health financing in improving health system performance FY03-FY12. 2013. http://ieg. worldbankgroup.org/Data/reports/AP Health financing eval.pdf.

3 United Nations. Adopting consensus text, general assembly encourages member states to plan, pursue transition of national health care systems towards universal coverage. 2012. http://www.un.org/press/ en/2012/ga11326.doc.htm.

World Health Organization. Positioning health in the post-2015 development agenda. 2012. www. who.int/topics/millennium_development_goals/ post2015/WHOdiscussionpaper_October2012.pdf. Gostin LO, Friedman EA. A retrospective and prospective analysis of the west African Ebola virus disease epidemic: robust national health systems at the foundation and an empowered WHO at the apex. Lancet 2015;385:1902-9. doi:10.1016/S01406736(15)60644-4

6 Moon S, Sridhar D, Pate MA, et al. Will Ebola change the game? Ten essential reforms before the next pandemic. The report of the Harvard-LSHTM Independent Panel on the Global Response to Ebola. Lancet 2015;386:2204-21. doi:10.1016/S01406736(15)00946-0

O'Connell T, Rasanathan K, Chopra M. What does universal health coverage mean?Lancet 2014:383:277-9. doi:10.1016/ S0140-6736(13)60955-1

8 World Health Organization. The world health report 2000: health systems: improving performance. 2000. http://www.who.int/whr/2000/en/.

9 World Bank. Healthy development: the World Bank strategy for health, nutrition, and population results. 2007. http://documents.worldbank.org/curated/ en/102281468140385647/Healthy-Developmentthe-World-Bank-strategy-for-health-nutritionpopulation-results.

10 Plsek PE, Greenhalgh T. Complexity science: the challenge of complexity in health care. BM/ 2001:323:625-8. doi:10.1136/ bmj.323.7313.625

11 United Nations. Transforming our world: the 2030 agenda for sustainable development. 2015. https://sustainabledevelopment.un.org/content/ documents/21252030\%20Agenda\%20for\%20 Sustainable\%20Development\%20web.pdf.

12 Kutzin J, Sparkes SP. Health systems strengthening, universal health coverage, health security and resilience. Bull World Health Organ 2016;94:2. doi:10.2471/BLT.15.165050

13 Independent Evaluation Group. Approach paper: evaluation of the World Bank's assistance for health, nutrition, and population. 2007. https://ieg. worldbankgroup.org/Data/reports/hnp_app_paper. pdf.

14 Unicef Programme Division. Unicef's Strategy for Health (2016-2030). 2015. www.unicef.org/health/ files/UNICEF Health Strategy Final.pdf.

15 Fernandes G, Sridhar D. World Bank and the Global Financing Facility. BMJ 2017;358:j3395.

16 Institute for Health Metrics and Evaluation. Development assistance for health database 1990-2015. 2016. http://ghdx.healthdata. 
org/record/development-assistance-healthdatabase-1990-2015.

17 Institute for Health Metrics and Evaluation. Development assistance for health database 1990-2016. 2017. http://ghdx.healthdata. org/record/development-assistance-healthdatabase-1990-2016.

18 Winters J, Sridhar D. Earmarking for global health: benefits and perils of the World Bank's trust fund model. BMJ 2017;358:13394.

19 Independent Evaluation Group. Program-for-Results: an early stage assessment of the process and effects of a new lending instrument. 2016. https://ieg. worldbankgroup.org/Data/Evaluation/files/programfor-results-full.pdf.

20 World Bank. Appraisal of a population project: Jamaica. 1970. http://documents.worldbank.org/ curated/en/483341468044661451/pdf/multipage.pdf.

21 World Bank. Financing health services in developing countries: an agenda for reform 1986. http://documents.worldbank.org/curated/ en/468091468137379607/Financing-healthservices-in-developing-countries-an-agenda-for-reform

22 Abbasi K. The World Bank on world health: under fire. BMJ 1999;318:1003-6. doi:10.1136/ bmi.318.7189.1003

23 Ridde V. "The problem of the worst-off is dealt with after all other issues": the equity and health policy implementation gap in Burkina Faso. Soc Sci Med 2008;66:1368-78. doi:10.1016/j. socscimed.2007.10.026

24 Johnston T, Stout S. Investing in health: development effectiveness in the health, nutrition, and population sector. World Bank, 1999. https://ieg. worldbankgroup.org/Data/reports/hnp.pdf.

25 Independent Evaluation Group. Do health sectorwide approaches achieve results? Emerging evidence and lessons from six countries. 2009. http://siteresources.worldbank.org/ EXTWBASSHEANUTPOP/Resources/wp4.pdf

26 WHO. World Bank. Tracking universal health coverage: first global monitoring report. 2015. www. who.int/healthinfo/universal_health_coverage/ report/2015/en.

27 Marriott A, Hamer J. Investing for the few: the IFC's Health in Africa Initiative. Oxfam International, 2014. http://policy-practice.oxfam.org.uk/publications/ investing-for-the-few-the-ifcs-health-in-africainitiative-325654

28 Sridhar D, McKee M, Ooms G. Universal health coverage and the right to health: from legal principle to post-2015 indicators. Int I Health Serv 2015:45:495-506. doi: $10.1177 / 0020731415584554$

29 Ghebreysus TA. Press conference transcript. 2017. http://www.who.int/dg/dg-elect/New DirectorGeneral_Tedros_VPC_24MAY2017.pdf?ua=1.

30 World Bank. World Bank group president Jim Yong Kim's speech at World Health Assembly: poverty, health and the human future. 2013. www.worldbank. org/en/news/speech/2013/05/21/world-bankgroup-president-jim-yong-kim-speech-at-worldhealth-assembly.

31 Tichenor M. Data performativity, performing health work: malaria and labour in Senegal. Med Anthropol 2017:1-13.
32 George S. What Thailand can teach the world about universal healthcare. Guardian 2016. www.theguardian.com/health-revolution/2016/ may/24/thailand-universal-healthcare-ucs-patientsgovernment-political.

33 World Health Organization. Brazil's march towards universal coverage. Bull World Health Organ 2010;88:646-7. doi:10.2471/ BLT.10.020910

34 Bump JB. The long road to universal health coverage: a century of lessons for development strategy. Rockefeller Foundation, 2010.

35 Welch C, Pecenka C. Health in the post-2015 development agenda: report of the Global Thematic Consultation on Health. http://apps.who.int/iris/ bitstream/10665/85535/1/9789241505963 eng.pdf.

36 World Bank Group Finances. Paid in contributions to IBRD/IDA/IFC trust funds based on FY of receipt. https://finances.worldbank.org/Trust-Funds-andFIFs/Paid-In-Contributions-to-IBRD-IDA-IFC-Trust Funds-/nh5z-5qch.

37 World Health Organization. Monitoring health for the SDGs: sustainable development goals, world health statistics. 2016. www.who.int/gho/publications/ world health statistics/2016/en.

38 World Health Organization. The Global Fund strategic approach to health systems strengthening. 2007. www.who.int/healthsystems/GF_strategic approach_\%20HS.pdf.

Cite this as: BMJ 2017;358:j3347

http://dx.doi.org/10.1136/bmi.j3347

This is an Open Access article distributed in accordance with the terms of the Creative Commons Attribution (CC BY 4.0) license, which permits others to distribute, remix, adapt and build upon this work, for commercial use, provided the original work is properly cited. See: http:// creativecommons.org/licenses/by/4.0/. 